\title{
6. Lessons from the Obama White House: how climate policy really gets done
}

\section{Alice C. Hill}

On January 20, 2009, then 47-year-old Barack Obama stood on the steps of the United States Capitol, his wife, Michelle Obama, by his side. He placed his left hand on the Bible held by his wife, raised his right hand, and took the oath of office to become the 44th President of the United States of America. The son of a white mother from Kansas and a black father from Africa, his inauguration was historic for many reasons. Not least among them was the fact that he would be the first president of the United States to develop a plan to tackle multiple aspects of climate change - mitigating greenhouse gas emissions, preparing for the impacts, and leading internationally on climate change policy. Just days before the November 2008 election, Obama vowed that his presidency "would mark a new chapter in America's leadership on climate change that will strengthen our security and create millions of new jobs in the process." It would take two terms in office to accomplish that vision. But, at the end of eight years in the White House, Obama left a legacy of climate policy that set the country on the course of, for the first time ever, tackling the dire threat of global warming. For those efforts, he has earned place in history as the "first climate president."

This chapter examines how President Obama wrote that new chapter on United States climate policy. It looks at how, despite limited success in his first term, the president used his second term to significant advantage in achieving historic progress on climate change. Three factors contributed greatly to that progress. First, Superstorm Sandy struck right before the 2012 presidential election and provided the nation with a graphic illustration of what was at stake with climate change. The president and his team almost immediately put that picture to good use as they advocated for increased climate action. Second, winning his re-election campaign in many ways freed the president from worrying about political opposition to his climate efforts. Re-election allowed him to push climate policies despite strong political headwinds. And, third, once safely re-elected, the president recruited the consummate political 
insider, John Podesta, to set the framework for accomplishing his climate goals. Podesta was put in charge of making sure the federal bureaucracy did what it was supposed to do and then communicating, communicating, and communicating some more about what the executive branch was doing to fight climate change.

\section{OBAMA'S UNEVEN START}

Almost immediately after President Obama first took office in January 2009, he started writing the first lines of the new climate chapter he had promised to the American people. More than three decades earlier, the National Academy of Sciences had warned then President Jimmy Carter that because the climate system had a "built-in time delay," postponing action on climate change until the impacts emerged was in fact the "riskiest strategy." "After Carter's defeat in 1980, however, the issue received scant presidential attention. ${ }^{4}$ Precious time had been lost and now President Obama had a chance to finally reverse course.

He quickly issued an executive order establishing the White House Office of Energy and Climate Change Policy and appointed a climate czar to run it. Within his first month in office, and with the global economy in freefall, he signed a $\$ 787$ billion stimulus package that included a host of "green" programs to promote clean energy, battery development, improvements to the electrical grid, and energy efficiency. A Climate Change Adaptation Task Force with representatives from over 20 federal agencies was launched. And in October 2009, Obama issued his first executive order directing federal agencies to set goals for sustainability and begin adaptation planning.

But as early as the summer of 2009, it was reported that the White House had come to view discussions about climate change as a political liability. ${ }^{5}$ In subsequent months, momentum began to falter. Just shy of finishing his first year in office, Obama appeared in the final hours of the United Nations Framework Convention on Climate Change Conference of Parties in Copenhagen. His performance, however, proved a major disappointment to attendees when the talks resulted in an agreement that fell far short of original hopes for reductions in emissions. ${ }^{6}$ The outcome was so bare bones that even Obama himself conceded that people were "justified in being disappointed." And then the 2010 mid-term elections saw the Republicans gain control of the US House of Representatives, which gave the president, in his own words, a "shellacking."

By the following summer, Obama's signature legislative push to cut greenhouse gas emissions, known as the Waxman-Markey Bill, died in the Senate before it even came to a vote. In 2011, the White House Office of Energy and Climate Change Policy folded after Congress denied funding. Obama's stimulus package, the American Recovery and Reinvestment Act of 
2009, contained provisions to increase spending on green energy but received withering partisan criticism for financing a half-billion-dollar loan to a solar manufacturer called Solyndra that subsequently went bankrupt. ${ }^{9}$ The administration failed to issue the Clean Power Plan despite a settlement agreement that required the Environmental Protection Agency (EPA) to publish final rules for new and existing power plants' emissions by May 2012. ${ }^{10}$ To be sure, there were successes, including an historic agreement with automakers to improve fuel efficiency standards, a measure they had long resisted. Yet, despite some progress, in Obama's January 2012 State of the Union Address, the issue of climate change received nothing more than a glancing mention. ${ }^{11}$ During the entire 2012 campaign season, neither he nor his Republican opponent Mitt Romney seemed to have any public appetite for the issue. ${ }^{12}$ Neither they, nor the moderators, raised it during the public candidate debates.

Toward the end of President Obama's first term, environmentalists reportedly started marking the number of months that went by between times the president uttered the phrase "climate change." 13 As Daniel Kammen, founding director of the Renewable \& Appropriate Energy Laboratory at the University of California, Berkeley, put it, "The first term was essentially lost territory."14

\section{A BOOST FROM SUPERSTORM SANDY}

Superstorm Sandy struck on October 29, 2012, just days before the 2012 presidential election. It was, no question, a serious crisis for the president and the nation. Sandy impacted 24 states, stretching roughly 1000 miles in diameter. ${ }^{15}$ It cut off power to more than 8 million people. ${ }^{16}$ The storm caused what was then the second largest blackout in US history, and the third largest overall. ${ }^{17}$ Without power, daily life ground to a halt for people as the region's economy and infrastructure sputtered. Schools were closed, hospitals were evacuated, and planes and trains stopped running. ${ }^{18}$

Just days after the storm struck, President Obama was re-elected. He and his team would adhere to the advice his first Chief of Staff, Rahm Emanuel, famously offered shortly before Obama's first election, namely, "You never want a serious crisis to go to waste." 19 Sandy had given the nation a graphic lesson on just how painful the impacts of climate change would be. In its wake, the Obama administration would repeatedly invoke Superstorm Sandy to push for greater climate action by the United States. Indeed, when President Obama issued his Climate Action Plan the summer after Sandy, he again referenced the storm, noting, "We can choose to believe that Superstorm Sandy, and the most severe drought in decades, and the worst wildfires some state have ever seen were all just a freak coincidence. Or we can choose to believe in the overwhelming judgment of science - and act before it's too late."20 
Throughout Obama's second term, members of his administration continued to reference Sandy, as they sought to push a climate agenda. In 2014, Obama directed the Department of Energy to conduct a quadrennial energy review to look at vulnerabilities from climate change, including the type of fallout from the failure of the energy sector during Sandy ${ }^{21}$ In 2015, building on a recommendation from the Hurricane Sandy Rebuilding Task Force, President Obama issued an executive order requiring all future federal investments in or near the floodplain to be resilient to climate change-exacerbated flooding. In 2015, the president's National Security Advisor, Susan Rice, referenced the storm and its destruction in a policy speech about the need to prepare for the national security risks from climate change. ${ }^{22} \mathrm{On}$ the third anniversary of the storm, Shaun Donovan, the head of the Office of Management and Budget in the White House, wrote that since Superstorm Sandy, the Obama administration had "led the Federal government in integrating resilience into the fabric of how we build, rebuild, plan, and prepare for the impacts of climate change." ${ }^{23}$

\section{THE NO-HOLDS-BARRED SECOND-TERM AGENDA}

When President Obama won his re-election campaign, he was largely set free from the political constraints on climate change that had hampered his first four years. He immediately "put energy and the environment at the top of his second-term agenda." ${ }^{24}$ Indeed, in his second inaugural address on January 21,2013 , he pledged that his administration would "respond to the threat of climate change, knowing that the failure to do so would betray our children and future generations. ${ }^{.25} \mathrm{He}$ took a no-holds-barred approach to achieving historic results in the fight to address global warming.

And the accomplishments began to roll. In the summer of 2013, he announced his Climate Action Plan on a sweltering July day in Washington, DC during a speech devoted solely to climate change. Cobbled together in secrecy in the White House, that plan set out his overall vision for climate change - mitigating greenhouse gas emissions, preparing for the impacts, and leading internationally on climate change policy. In the face of Congressional inaction, Obama increasingly focused on what he could accomplish by going it alone. He issued executive order after executive order, created hundreds of climate policies, and went on to reach the historic Paris Agreement in 2015. ${ }^{26}$ His climate policies ranged from creating a wildfire building standard for federal buildings to issuing the Clean Power Plan to requiring the national security apparatus to plan for the national security risks posed by climate change. He also put one of the most effective insiders in Washington, John Podesta, in charge of his climate efforts. Podesta had served as President Bill Clinton's Chief of Staff, was an ardent environmentalist, and knew how to 
navigate Washington's bulging bureaucracy. Podesta offered the necessary leadership to make sure the president's climate agenda was accomplished.

\section{"BEFORE PODESTA AND AFTER PODESTA"}

In late 2013, President Obama recruited John Podesta to serve as his counselor. John Podesta had served as White House Chief of Staff to President Bill Clinton and spent years working on Capitol Hill in various positions. He also founded the Center for American Progress, a progressive think tank in Washington. ${ }^{27}$ Podesta had a reputation for knowing how to get things done in Washington and Obama wanted him to oversee the implementation of the Climate Action Plan. ${ }^{28}$ Podesta's arrival marked a change in the White House's approach to climate work. Or, as one Democratic strategist put it according to the Atlantic, "You can divide the Obama administration's environmental policy-making into BP and AP. Before Podesta and After Podesta."29

Shortly after his arrival, Podesta gathered White House officials and agency leaders for a Saturday morning meeting to scope out the implementation of the Climate Action Plan in the coming year. The meeting covered everything from creating a sense of urgency in the American public to increasing resilience to issuing EPA rules for lowering emissions. Podesta established a regular meeting schedule for leaders across the federal agencies working on the president's climate agenda.

He put to good use his experience working with Washington's notoriously ponderous bureaucracy. For the newly created "climate team," he made clear that, at least for purposes of his weekly climate meetings, reports of hosting a meeting or making contact with potential collaborators carried little value. Of course Podesta knew that such meetings were necessary. But having a meeting was different from achieving results. Podesta was interested in results. He wanted to hear about policies, initiatives, and partnerships created and acted upon. It did not take long for those assembled to assimilate the lesson he conveyed. They sensed that, under Podesta's leadership, they had a precious opportunity to change the trajectory on climate change.

Podesta supported the use of executive orders to accomplish goals that would otherwise die on Capitol Hill. He conveyed to federal bureaucrats and political appointees alike that now was the time to get climate policy done. He brokered fights between competing agencies, including one over the scope of a federal flood risk management standard to avoid Superstorm Sandy-like flood damage in the future. Podesta's weekly climate meetings began yielding identifiable results. The Obama administration had begun to deliver a startling array of accomplishments, ranging from the release of masses of federal climate data to new pollution standards for power plants to the billion-dollar National Disaster Resilience Competition. According to Todd Stern, the State 
Department's climate envoy, Podesta understood "how to make things happen, and how to make things work in an administration and from the perch of the White House. ${ }^{\prime 30}$

Podesta also insisted that the White House communications team develop a strategy and schedule to communicate every new climate policy. The team created a rhythm of announcements, making sure that some new project, initiative, or policy hit the news cycle every week. A constant flow of fresh announcements succeeded in creating a public impression that the entire federal government was firing on all cylinders to combat climate change. ${ }^{31}$ And that flow lasted up to the very last days of President Obama's second term.

\section{WILL IT BE ENOUGH?}

Just as Barack Obama's first inauguration was historic, so was his presidency. He proved himself to be the first climate president. Taking advantage of Sandy's destruction to make the case for further climate action and bringing in a consummate political insider to craft the efforts, Obama pushed forward a climate agenda that remains unprecedented in its scope and range. The effort, of course was warranted. As he observed, "No challenge - no challenge poses a greater threat to future generations than climate change." ${ }^{\prime 32}$

Yet, the election of the 45th President of the United States, Donald J. Trump, has made clear that even an historic effort in a second term may not be able to withstand a change in who occupies the White House. Much of the fine policy work done by President Obama and his team began to unravel almost immediately after the new president placed his hand on the Bible and was sworn into office. President Obama's second-term climate policy accomplishments proved highly vulnerable to undoing by a president who called climate change a "hoax." ${ }^{33}$ Undoubtedly, Obama left an historic legacy on climate change. The question that remains, as even Podesta, his trusted counselor, has noted, is whether "50 years from now, is that going to seem like enough?" 34

\section{NOTES}

1. John M. Broder, "Obama affirms climate change goals," New York Times, November 18, 2008, accessed August 17, 2020 at https://www.nytimes.com/2008/ 11/19/us/politics/19climate.html.

2. John Abraham, "Barack Obama is the first climate president," The Guardian, November 2, 2016, accessed August 17, 2020 at https://www.theguardian.com/ environment/climate-consensus-97-per-cent/2016/nov/02/barack-obama-is-the -first-climate-president.

3. Claude Henry and Laurence Tubiana, Earth at Risk (New York: Columbia University Press, 2018), p. 78.

4. Ibid., p. 81 . 
5. Suzanne Goldenberg, "Revealed: the day Obama chose a strategy of silence on climate change," The Guardian, November 1, 2012, accessed August 17, 2020 at https://www.theguardian.com/environment/2012/nov/01/obama-strategy-silence -climate-change.

6. Suzanne Goldenberg and Aleggra Stratton, "Barack Obama's speech disappoints and fuels frustration at Copenhagen," The Guardian, December 18, 2009, accessed August 17, 2020 at https://www.theguardian.com/environment/2009/ dec/18/obama-speech-copenhagen.

7. Alister Bull and Tabassum Zakaria, "Obama says disappointment at Copenhagen justified," Reuters, December 23, 2009, accessed August 17, 2020 at https:// www.reuters.com/article/us-obama-climate/obama-says-disappointment-at -copenhagen-justified-idUSTRE5BM4DO20091224.

8. Liz Halloran, "Obama humbled by election 'shellacking'," NPR, November 3, 2010, accessed August 17, 2020 at https://www.npr.org/templates/story/story.php ?storyId=131046118.

9. Joe Stephens and Carol D. Leonnig, "Documents show politics infused Obama 'green' programs," Washington Post, December 25, 2011, accessed August 17, 2020 at https://www.washingtonpost.com/solyndra-politics-infused-obama -energy-programs/2011/12/14/gIQA4HllHP_story.html.

10. Environmental Protection Agency, Notice: "Proposed settlement agreement, Clean Air Act citizen suit,” Federal Register 75, No. 250 (2010): 82392-3, accessed August 17, 2020 at https://www.federalregister.gov/documents/2010/12/ 30/2010-32935/proposed-settlement-agreement-clean-air-act-citizen-suit.

11. Barack Obama, "State of the Union Address," January 24, 2012, American Presidency Project, accessed August 17, 2020 at https://www.presidency.ucsb .edu/documents/address-before-joint-session-the-congress-the-state-the-union -15 .

12. John M. Broder, "Both Romney and Obama avoid talk of climate change," New York Times, October 25, 2012, accessed August 17, 2020 at https://www.nytimes .com/2012/10/26/us/politics/climate-change-nearly-absent-in-the-campaign.html.

13. Darren Samuelsohn, "The greening of Barack Obama," Politico, November 18, 2014, accessed August 17, 2020 at https://www.politico.com/story/2014/11/ barack-obama-environment-112974.

14. Marianne Lavelle, "2016: Obama's climate legacy marked by triumphs and lost opportunities," Inside Climate News, December 26, 2016, accessed August 17, 2020 at https://insideclimatenews.org/news/23122016/obama-climate-change -legacy-trump-policies.

15. Federal Emergency Management Agency (FEMA), Hurricane Sandy FEMA After-Action Report (Washington, DC: FEMA, 2013), pp. 1-4.

16. Office of Electricity Delivery and Energy Reliability, Comparing the Impacts of Northeast Hurricanes on Energy Infrastructure (Washington, DC: Department of Energy, 2013), p. iv, accessed August 17, 2020 at https://www.energy.gov/sites/ prod/files/2013/04/f0/Northeast\%20Storm\%20Comparison_FINAL_041513b .pdf.

17. Peter Marsters and Trevor Houser, "America's biggest blackout," rhg.com, October 26, 2017, accessed August 17, 2020 at https://rhg.com/research/americas -biggest-blackout-2/.

18. Alice C. Hill and William Kakenmaster, "Resilient infrastructure: understanding interconnectedness and long-term risk," in Optimizing Community Infrastructure: 
Resilience in the Face of Shocks and Stresses, ed. Ryan Cooker (Oxford: Elsevier, 2019).

19. Viveca Novak, "Bum rap for Rahm," FactCheck.org, January 13, 2011, accessed August 17, 2020 at https://www.factcheck.org/2011/01/bum-rap-for-rahm/.

20. Barack Obama, "State of the Union Address," February 12, 2013, American Presidency Project, accessed August 17, 2020 at https://www.presidency.ucsb .edu/documents/address-before-joint-session-congress-the-state-the-union-2.

21. Barack Obama, "Presidential memorandum - establishing a quadrennial energy review" (Washington, DC: Office of the White House, 2014).

22. Susan Rice, "Remarks on climate change and national security," speech, October 12, 2015, Stanford University, Palo Alto, California.

23. Shaun Donovan, "In ongoing response to Hurricane Sandy, we must remain focused on climate change's long-term impacts" [White House blog], October 29, 2015, accessed August 17, 2020 at https://obamawhitehouse.archives.gov/blog/ 2015/10/29/ongoing-response-hurricane-sandy-we-must-remain-focused-climate -changes-long-term.

24. John Deutch, "Obama's second-term energy policy is working," Wall Street Journal, August 18, 2014, accessed August 17, 2020 at https://www.wsj .com/articles/john-deutch-obamas-second-term-energy-policy-is-working -1408404210 .

25. Barack Obama, "Inaugural Address," January 21, 2013, American Presidency Project, accessed August 17, 2020 at https://www.presidency.ucsb.edu/documents/ inaugural-address- 15 .

26. White House, The Record: President Obama on Climate and Energy [video] (Washington, DC: Office of the White House, 2017), accessed August 11, 2020 at https://obamawhitehouse.archives.gov/featured-videos/video/2017/01/09/record -president-obama-climate-and-energy.

27. Podesta later served as chair of the 2016 Hillary Clinton presidential campaign.

28. Juliet Eilperin, "A year in the White House: John Podesta reflects on Obama's environmental record," Washington Post, February 23, 2015, accessed August 17, 2020 at https://www.washingtonpost.com/news/energy-environment/wp/2015/ 02/23/a-year-in-the-white-house-john-podesta-reflects-on-obamas-environmental -record/.

29. Ben Geman and National Journal, "The audacity of John Podesta," The Atlantic, November 21, 2014, accessed August 17, 2020 at https://www.theatlantic.com/ politics/archive/2014/11/the-audacity-of-john-podesta/446901/.

30. Ibid.

31. Ibid.

32. Barack Obama, "State of the Union Address," January 20, 2015, American Presidency Project, accessed August 17, 2020 at https://www.presidency.ucsb .edu/documents/address-before-joint-session-the-congress-the-state-the-union -20 .

33. Donald Trump (@realDonaldTrump), “Ice storm rolls from Texas to Tennessee I'm in Los Angeles and..." Twitter, December 6, 2013, 8:13 AM, accessed August 17, 2020 at https://witter.com/realDonaldTrump/status/408977616926830592?s= 20.

34. Colleen McCain Nelson and Carol E. Lee, "Former Clinton aide Podesta played key role in developing carbon rule," Wall Street Journal, June 3, 2014, accessed August 17, 2020 at https:/www.wsj.com/articles/former-clinton-aide-podesta -played-key-role-in-developing-carbon-emmissions-rule-1401839771. 